\title{
Anomalous Upper Devonian mercury enrichments: comparison of Inductively Coupled Plasma - Mass Spectrometry (ICP-MS) and Atomic Absorption Spectrometry (AAS) analytical data
}

\author{
Grzegorz RACKI $^{1, *}$, Leszek MARYNOWSKI ${ }^{1}$ and Michał RAKOCIŃSKI ${ }^{1}$ \\ 1 Silesian University, Department of Earth Sciences, Będzińska 60, PL-41-200 Sosnowiec, Poland
}

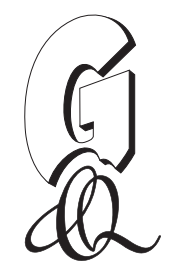

Racki, G., Marynowski, L., Rakociński, M., 2018. Anomalous Upper Devonian mercury enrichments: comparison of Inductively Coupled Plasma - Mass Spectrometry (ICP-MS) and Atomic Absorption Spectrometry (AAS) analytical data. Geological Quarterly, 62 (3): 487-495, doi: 10.7306/gq.1419

\begin{abstract}
Mercury geochemistry is emerging recently as a hot topic in chemostratigraphical and facies research, owing to the diagnostic character of $\mathrm{Hg}$ enrichments as a proxy of volcanic activity (crucial in the context of assumed causal links between volcanic cataclysms and mass extinctions). Thus, as a prerequisite to such far-reaching interpretations, reliable analytical determinations of $\mathrm{Hg}$ concentrations are necessary. In conventionally performed analyses in sedimentary geochemistry, Inductively Coupled Plasma - Mass Spectrometry (ICP-MS) is usually applied, as an analytical standard for trace elements, including $\mathrm{Hg}$. However, with a detection limit (DL) of $10 \mathrm{ppb}$, such measured values have been questioned as a conclusive geochemical indicator of $\mathrm{Hg}$ anomalies, and, instead, far more accurate techniques, such as Atomic Absorption Spectrometry (AAS; $D L=0.2 \mathrm{ppb}$ ), are requested. As a preliminary test of this view, we present comparative analysis of 91 samples from three sections encompassing the key Frasnian-Famennian and Famennian-Tournaisian boundary intervals in Morocco (Lahmida), Germany (Kahlleite) and Uzbekistan (Novchomok), for which Hg concentrations were determined by both methods in the same samples. Despite some differences, especially at low $\mathrm{Hg}$ concentrations, both analytical methods reveal the same 12 extraordinarily enriched samples in excess of $1 \mathrm{ppm}$ (with one exception, the determination error is <20\%), as well as similar overall chemostratigraphic patterns characterized by a few prominent Hg spikes, with a top value of 5.8 ppm. The $\mathrm{Hg}$ concentrations determined by ICP-MS and AAS are significantly correlated, as high as $r=0.98$ (Novchomok), even if the first method reveals a general tendency toward slightly heightened values (by 15 to $30 \%$ for medians). Therefore, ICP-MS results can conclusively be used in mercury chemostratigraphy in order to recognize extraordinary volcanic (or other) signals, at least in the Devonian geological record. False $\mathrm{Hg}$ anomalies were not generated by these conventional ICP-MS determinations.
\end{abstract}

Key words: Mercury anomalies, analytical methods, geochemistry, Frasnian-Famennian boundary, Devonian-Carboniferous boundary, volcanism.

\section{INTRODUCTION}

Despite great advances in sedimentary elemental geochemistry in the last few decades, focused on the use of trace elements to refine palaeoenvironmental reconstruction (e.g., Sagemann and Lyons, 2003; Tribovillard et al., 2006; Calvert and Pedersen, 2007; Ramkumar, 2015), mercury, in contrast to iridium, molybdenum, uranium, vanadium, barium and zirconium, used to be largely ignored in event chemostratigraphy and facies analysis. However, already Hildebrand and Boynton (1989) discovered "sub-ppm" Hg anomalies at three non-marine North American localities of the Cretaceous-Paleogene (K-Pg) boundary, and considered them as evidence for acid rain caused by a large meteorite impact (see similar data from Slovenia in Palinkaš et al., 1996).

* Corresponding author, e-mail: racki@us.edu.pl Received: March 5, 2018; accepted: April 21, 2018; first published online: June 13, 2018
The overlooked, seemingly trivial geochemical theme of extraordinarily concentrated levels of this chalcophile trace metal unexpectedly returned several years ago. The essential contribution of volcanic gaseous expulsions to the modern global mercury cycle is well-established (e.g., Pyle and Mather, 2003). Volcanogenic $\mathrm{Hg}$ is contained mainly in gaseous emissions, not in pyroclastic ash. Prior to deposition of oxygenated reactive $\mathrm{Hg}$ via rain, it can be distributed worldwide in the atmosphere because of the $\mathrm{Hg}$ residence time of $\sim 0.5-2$ years. $\mathrm{Hg}$ is scavenged during depositional processes by sedimentary organic matter, and also by absorption on clay minerals, sulphides (in oxygen-deficient conditions), and hydrous iron oxides (see Sanei et al., 2012; Percival et al., 2015; Sial et al., 2016; Bergquist, 2017; Sabatino et al., 2018). In the stratigraphical record, Nascimento-Silva et al. (2011) and Sanei et al. (2012) concurrently highlighted $\mathrm{Hg}$ anomalies as a record of catastrophic volcanic eruptions during the end-Cretaceous and end-Permian mass extinctions, respectively, while $\mathrm{Hg}$ was used as a marker of Neoproterozoic volcanism in Cryogenian deposits by Sial et al. (2010).

Since this discovery, a milestone in the debate on volcanism versus impact - mass extinction causal links (see a recentmost 
pro-impact synopsis in Rampino, 2017), many papers on anomalously enriched $\mathrm{Hg}$ concentrations have been published. Anomalies have been reported from major and second-order global events, including the end-Ordovician, end-Permian, end-Triassic, and end-Cretaceous extinctions, as well as-the Toarcian and Aptian-Albian oceanic anoxic events (for review see Bergquist, 2017; also Grasby et al., 2015; Percival et al., 2015, 2017; Sial et al., 2016; Bond and Grasby, 2017; Jones et al., 2017; Sabatino et al., 2018). Only the Late Devonian global events have remained unreported in this respect. Therefore, the occurrence and concentration of $\mathrm{Hg}$ in sedimentary rocks now appears to be a hot topic in event/chemostratigraphical research. In addition, mercury isotopes recorded as a marker of massive volcanism of Large Igneous Provinces (LIPs) remains an associated theme (Thibodeau and Bergquist, 2017). On the other hand, the direct role of toxic $\mathrm{Hg}$ contamination in biosphere devastation, originally stressed by Sanei et al. (2012), has shifted to a rather subordinate level ("has yet to be fully evaluated" - Bond and Grasby, 2017: p. 18).

Consequently, reliable analytical determinations of $\mathrm{Hg}$ abundances are a precondition for substantive geological interpretations. In sedimentary geochemistry, Inductively Coupled Plasma - Mass Spectrometry (ICP-MS) is applied as a standard analytical tool for a broad set of trace elements, including mercury. However, such conventionally measured $\mathrm{Hg}$ values, with a detection limit (DL) of $10 \mathrm{ppb}$, are questioned as a trustworthy proxy of volcanic paroxysms. Therefore, other refined techniques, such as Atomic Absorption Spectrometry (AAS; DL $=0.2 \mathrm{ppb}$ ), are commonly preferred. Furthermore, the "suspect quality" of $\mathrm{Hg}$ analytical data provided by ICP-MS might be a reason for rejecting manuscripts including this kind of data.

To test this view, we provide herein comparative ICP-MS and AAS analyses of 91 samples from three sections encompassing the key Frasnian-Famennian (F-F) and Devonian-Carboniferous (D-C) boundary interval in Morocco, Germany and Uzbekistan (Fig. 1) for which $\mathrm{Hg}$ concentrations were determined by both methods. This should help understand of analytical constraints on $\mathrm{Hg}$ applicability in sedimentary geochemistry, especially as a potential volcanogenic fingerprint. Detailed analysis and interpretation of the worldwide anomalous $\mathrm{Hg}$ spikes associated with the Upper Devonian biodiversity crises, first reported here for D-C transition, will be given elsewhere. However, at least the most distinctive $\mathrm{Hg}$ signal just below the F-F boundary is shown as a probable signature of cataclysmic volcanism that led to the global biodiversity collapse (Racki et al., 2018).

\section{SAMPLES AND METHODS}

We have analysed samples from three deep-water marly limestone successions (Figs. 1 and 2): Lahmida (Morocco; 43 samples), Kahlleite (Germany; 16 samples from the F-F boundary beds and 7 from the Devonian-Carboniferous transition), and Novchomok (Uzbekistan; 25 samples).

In palaeogeographic terms, the natural Lahmida section represents the deep-water Rheris shelf basin, on the southern periphery of the Rheic Ocean. The exposure is located $\sim 12 \mathrm{~km}$ to the north-west from Erfoud in the eastern part of the Anti-Atlas (Wendt and Belka, 1991; Dopieralska, 2003, 2009). The Moroccan succession consists mainly of monotonous shales with numerous marly interbeds and concretion horizons as well as dark grey limestones, which together with dark grey shales correspond to the expanded Kellwasser facies of the Rheris Basin (see Dopieralska, 2003). The thickness of the interval sampled is $\sim 36 \mathrm{~m}$. This succession was dated by conodonts but apart from zonal assignments (Fig. 2), faunal details have not yet been published. The succession shown includes the interval from the Middle Frasnian (MN Zone 5) to the top of the lower Famennian (rhomboidea Zone; Dopieralska, 2003).

The inactive (from 2013 on) Kahlleite Quarry is located 1 km south-west of Rüdersdorf near Gera, Thuringia, central Ger-

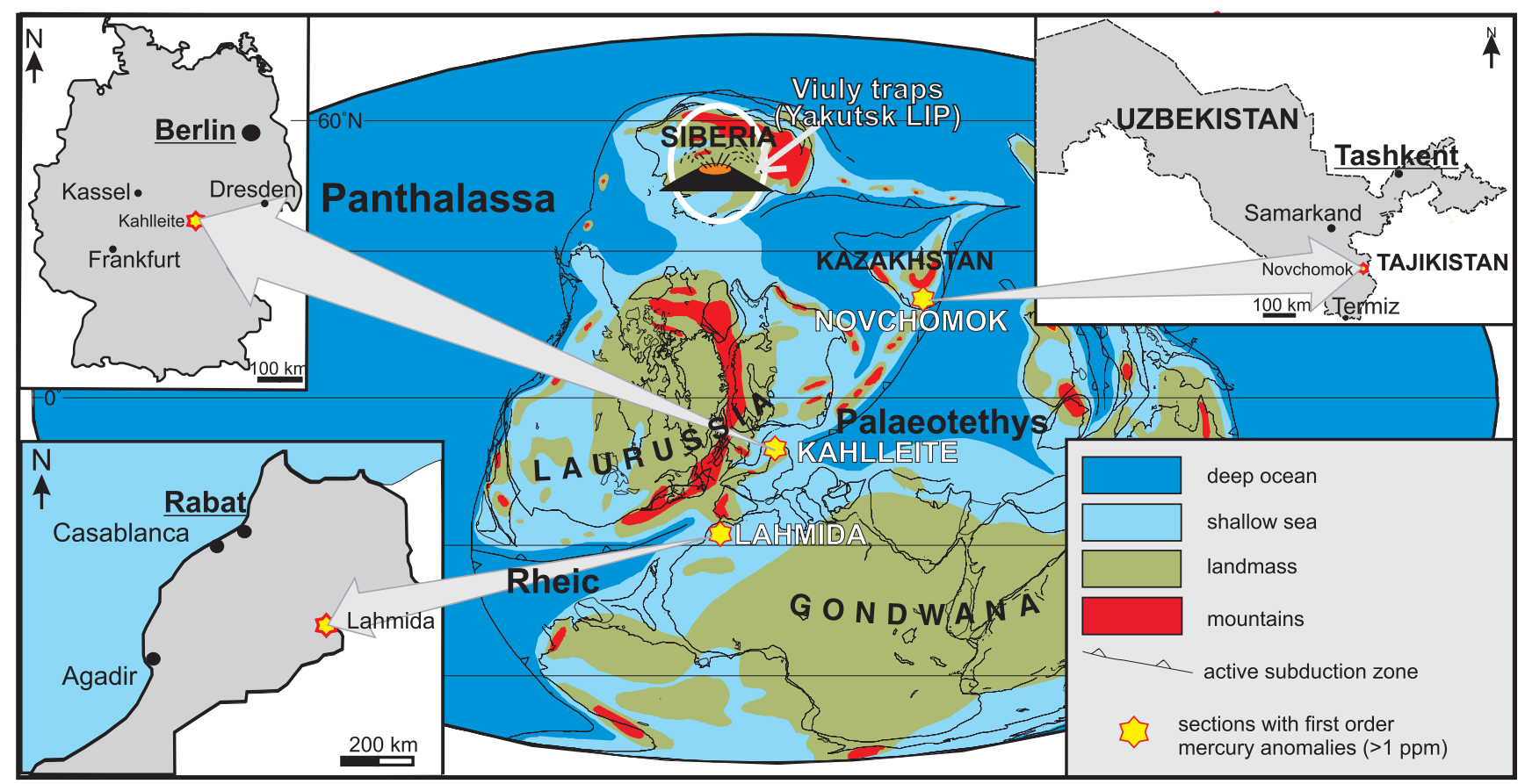

Fig. 1. Geographic and palaeogeographic locations of the Late Devonian sites studied for Hg abundances (Fig. 2), compared to inferred proximity to the coeval Siberian large igneous province (after Kravchinsky, 2012; Late Devonian palaeogeography after Golonka et al., 1994) 
A

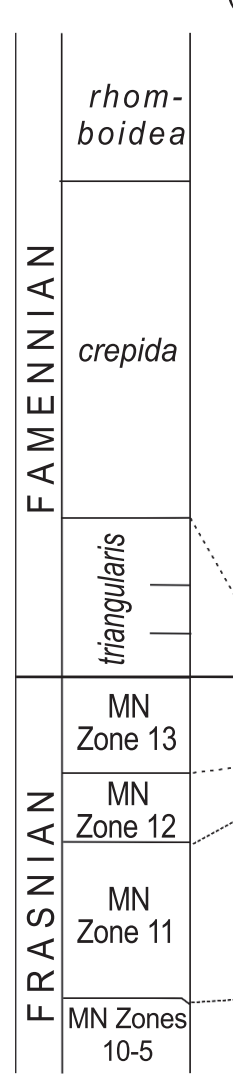

Lahmida

(Anti-Atlas, Morocco)
B

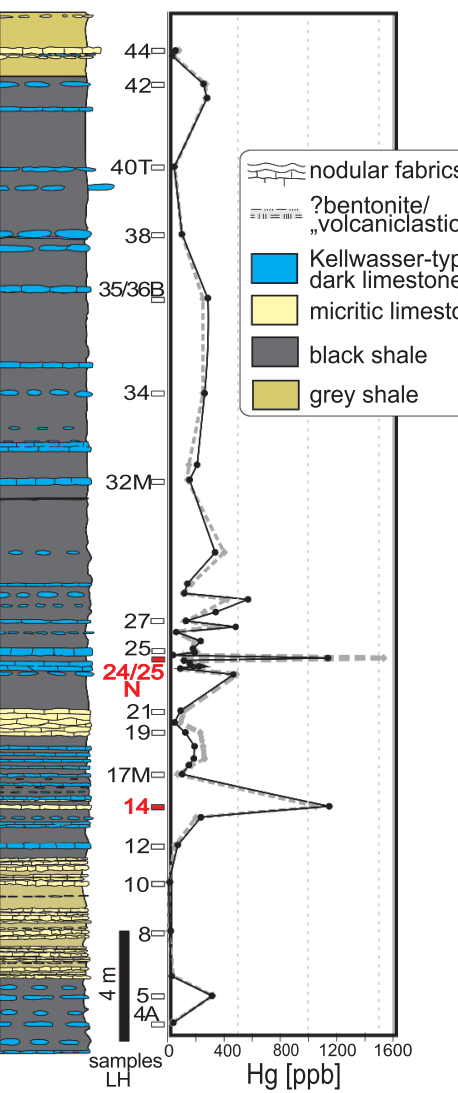

Kahhleite (Thuringia, Germany)

\section{Novchomok}

(Uzbekistan)
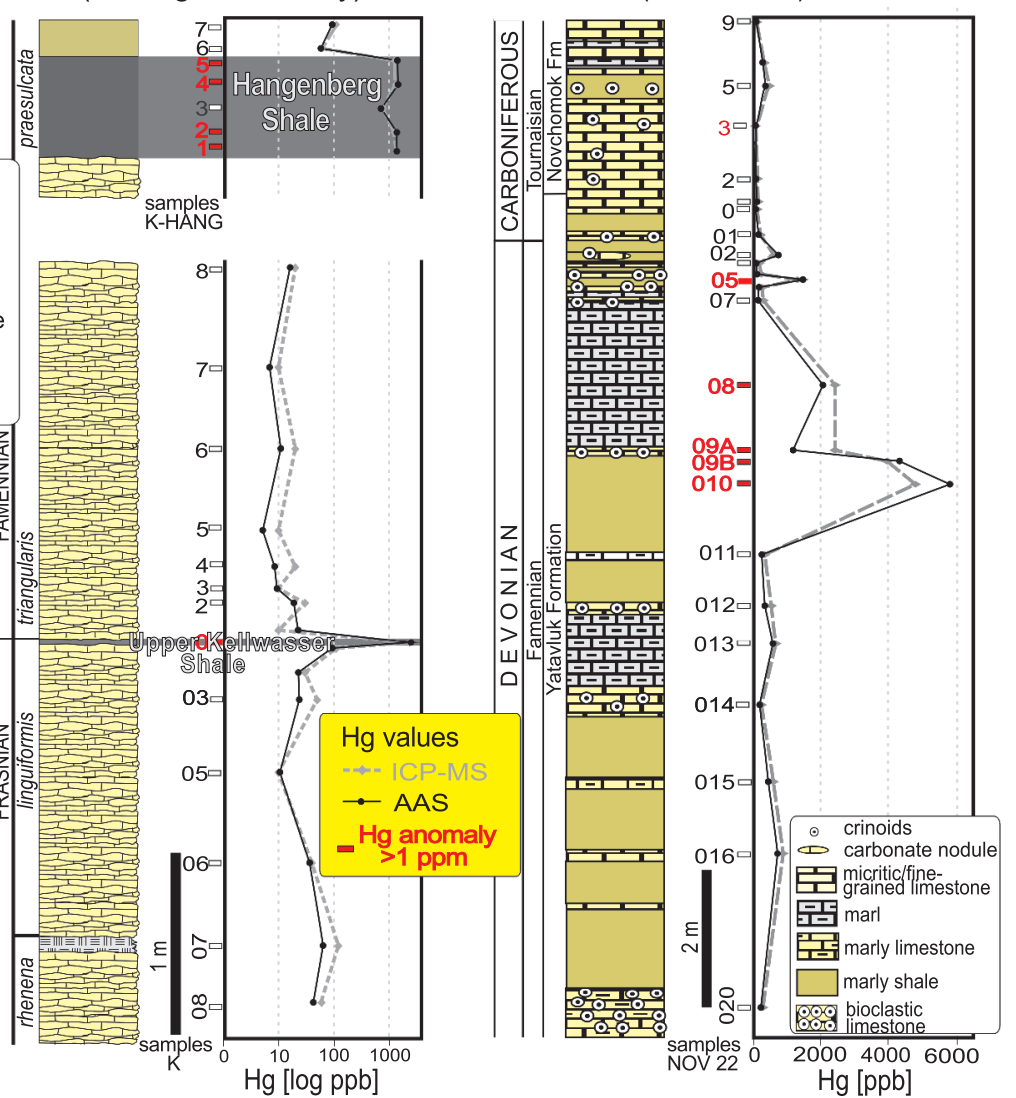

Fig. 2. Comparison of analytical Hg abundances provided by ICP-MS and ASS methods for Late Devonian sections in Morocco (A; after Dopieralska, 2003), Germany (B; after Gereke, 2004) and Uzbekistan (C), showing consistently large Hg anomalies in both the Hg data sets (Fig. 3), associated with the F-F and D-C boundaries (Tables 1-3), including the marker black shale Upper Kellwasser and Hangenberg levels at Kahlleite

many, at the north-west flank of the Berga Anticline (Gereke, 2004, 2007; Weyer, 2016; see also fig. 18 in Hartenfels, 2011) in the Saxothuringian Zone (Eckelmann et al., 2014, Franke et al., 2017). The succession stretched from the Mid-Upper Frasnian to the Mid-Upper Tournaisian (Weyer, 2016). Two intervals were sampled, that encompass marker Upper Devonian black shale levels: the Upper Kellwasser (3.5 cm thick) and Hangenberg ( $30 \mathrm{~cm}$ thick). The beds consist largely of grey nodular-micritic limestones, deposited on a deep submarine rise belonging to the outer southern shelf of the closing Rheic Ocean (Gereke and Schindler, 2012; Eckelkmann et al., 2014; Saupe et al., 2016; Franke et al., 2017).

The Novchomok (22) site is located in the eastern part of the Kitab Geological Reserve Area, lying in the Zeravshan-Gissar Mountains area (western part of Tian-Shan, south Uzbekistan; see Narkiewicz et al., 2017). The Devonian-Carboniferous boundary interval sampled, $17 \mathrm{~m}$ thick, comprises the top part of the Yatavluk Formation and the basal slice of the Novchomok Formation. The lower part (Yatavluk Fm.) consists mostly of dark grey micritic limestones with crinoid detritus and corals, and includes also cherry-coloured and grey marly shales and marls. The upper portion (Novchomok Fm.) is composed of dark grey, mostly micritic limestones and brown marly shales, locally with crinoids. The D-C boundary, based on conodonts, was tentatively traced just below the top of the Yatavluk Formation by Narkiewicz et al. (2017). The Devonian and Carboniferous strata were deposited on the passive margin of the
Tarim plate, as terranes of Perigondwana then approached Kazakh terranes with closing of the South Tianshan Ocean (Golonka, 2012; Han and Zhao 2018; see also Stampfli and Borel, 2002).

\section{MERCURY DETERMINATION}

The Hg concentration of bulk rock samples from the three sections studied were analysed using two independent geochemical methods (Fig. 2; Tables 1-3). Conventional ICP-MS analyses were provided commercially by Bureau Veritas AcmeLabs, Vancouver, Canada. STD DS10 standard material was the principal reference, with a certified $\mathrm{Hg}$ abundance of $289 \mathrm{ppb}$. The mercury concentration of the reference analysed in the laboratory was within $13 \%$ of its expected $\mathrm{Hg}$ value. However, when another STD, OREAS45EA, was considered, with a low certified $\mathrm{Hg}$ value of $30 \mathrm{ppb}$ (registered in our 2011 analyses), i.e., near the method's detection limit (10 ppb), the accuracy error is far greater, reaching $>60 \%$. Selected samples were measured in duplicates, showing reproducibility better than $\pm 5 \%$.

For atomic absorption spectrometry (AAS), a two-cell, pyrolyzer-type Milestone DMA-80 Direct Mercury Analyzer was used, with a detection limit of $0.2 \mathrm{ppb}$. Analyses were performed at the Faculty of Earth Sciences, University of Silesia (Poland). 
Table 1

Hg abundances in 43 samples from the Lahmida section using ICP-MS and AAS methods ( $\mathrm{Hg}$ enrichments $>0.5 \mathrm{ppm}$ in AAS values are highlighted)

\begin{tabular}{|c|c|c|c|}
\hline \multirow{3}{*}{ Stage } & Sample & $\mathrm{Hg}$ & $\mathrm{Hg}$ \\
\hline & Method & ICP-MS & AAS \\
\hline & Method detection limit (MDL) & $10 \mathrm{ppb}$ & $0.2 \mathrm{ppb}$ \\
\hline \multirow{21}{*}{ FAMENNIAN } & LA 44 & 80 & 54.5 \\
\hline & LA 43/44 & 40 & 31.2 \\
\hline & LA 42 & 270 & 250.0 \\
\hline & LA $41 / 42$ & 270 & 276.6 \\
\hline & LA 40T & 50 & 44.8 \\
\hline & LA 38 & 100 & 99.8 \\
\hline & LA 35/36B & 250 & 283.2 \\
\hline & LA 34 & 250 & 260.0 \\
\hline & LA $32 / 33$ & 150 & 207.0 \\
\hline & LA 32M & 140 & 153.2 \\
\hline & LA 30 & 400 & 333.8 \\
\hline & LH 29 & 170 & 137.5 \\
\hline & LH 28 & 110 & 114.0 \\
\hline & LH $27 A 2$ & 420 & 569.1 \\
\hline & LA $27 / 28$ & 260 & 338.4 \\
\hline & LH 27 & 120 & 126.4 \\
\hline & LA $26 / 27$ & 360 & 481.2 \\
\hline & LH 26 & 60 & 57.3 \\
\hline & LA 25/26 & 190 & 232.5 \\
\hline & LH 25T & 180 & 180.1 \\
\hline & LH 25B & 210 & 189.3 \\
\hline \multirow{22}{*}{ FRASNIAN } & LA 24/25S & 110 & 36.9 \\
\hline & LA $24 / 25 \mathrm{~N}$ & 1530 & 1136.4 \\
\hline & LH 24T & 110 & 113.2 \\
\hline & LH 24B & 190 & 153.7 \\
\hline & LH 23T & 250 & 219.0 \\
\hline & LH 23B & 90 & 90.0 \\
\hline & LH 22 & 490 & 464.2 \\
\hline & LH 21 & 120 & 90.3 \\
\hline & LH 20 & 90 & 45.7 \\
\hline & LH 19 & 230 & 123.0 \\
\hline & LH 18 & 250 & 187.7 \\
\hline & LA 17/18T & 260 & 183.2 \\
\hline & LA 17/18B & 170 & 147.8 \\
\hline & LA 17M & 70 & 99.9 \\
\hline & LA 14 & 1050 & 1144.9 \\
\hline & LA 13T & 200 & 233.1 \\
\hline & LA 12 & 50 & 68.8 \\
\hline & LA 10 & $<10^{*}$ & 6.8 \\
\hline & LA 8 & $<10^{*}$ & 9.9 \\
\hline & LA 6 & 30 & 25.9 \\
\hline & LA 5 & 320 & 312.3 \\
\hline & LA 4A & 30 & 36.9 \\
\hline \multicolumn{2}{|c|}{ Median/mean value } & $175 / 226$ & $153.2 / 217.4$ \\
\hline \multicolumn{2}{|c|}{ Linear correlation coefficient } & \multicolumn{2}{|c|}{0.96} \\
\hline \multicolumn{2}{|c|}{ Spearman's rs correlation coefficient } & \multicolumn{2}{|c|}{0.95} \\
\hline
\end{tabular}

*Taken as $8 \mathrm{ppb}$ in calculation of correlation coefficients 
$\mathrm{Hg}$ abundances in samples from the Kahlleite section using ICP-MS and AAS methods ( $\mathrm{Hg}$ enrichments $>0.5 \mathrm{ppm}$ in AAS values are highlighted)

\begin{tabular}{|c|c|c|c|}
\hline \multirow{3}{*}{ Stage } & Sample & $\mathrm{Hg}$ & $\mathrm{Hg}$ \\
\hline & Method & ICP-MS & AAS \\
\hline & Method detection limit (MDL) & 10 ppb & $0.2 \mathrm{ppb}$ \\
\hline \multirow{15}{*}{ FAMENNIAN } & K-HANG 7 & 110 & 92.9 \\
\hline & K-HANG 6 & 60 & 58.4 \\
\hline & K-HANG 5 & 1300 & 1504.9 \\
\hline & K-HANG 4 & 1350 & 1529.0 \\
\hline & K-HANG 3 & 790 & 753.3 \\
\hline & K-HANG 2 & 1280 & 1456.4 \\
\hline & K-HANG 1 & 1380 & 1438.3 \\
\hline & K 8 & 20 & 16.2 \\
\hline & K 7 & $<10^{*}$ & 6.9 \\
\hline & $\mathrm{K} 6$ & 20 & 11.0 \\
\hline & $\mathrm{K} 5$ & $<10^{*}$ & 5.2 \\
\hline & $\mathrm{K} 4$ & 20 & 8.5 \\
\hline & K 3 & $<10^{*}$ & 9.3 \\
\hline & $\mathrm{K} 2$ & 30 & 18.9 \\
\hline & $\mathrm{K} 1$ & $<10^{*}$ & 22.5 \\
\hline \multirow{8}{*}{ FRASNIAN } & $\mathrm{KO}$ & 2380 & 2517.3 \\
\hline & K 01 & 110 & 93.0 \\
\hline & $\mathrm{K} 02$ & 30 & 22.7 \\
\hline & $\mathrm{K} 03$ & 50 & 23.6 \\
\hline & K 05 & 10 & 10.6 \\
\hline & K 06 & 40 & 36.4 \\
\hline & K 07 & 120 & 63.3 \\
\hline & K 08 & 60 & 42.1 \\
\hline \multicolumn{2}{|c|}{ Median/mean value } & $50 / 400$ & $36.4 / 423.5$ \\
\hline \multicolumn{2}{|c|}{ Linear correlation coefficient } & \multicolumn{2}{|c|}{1.00} \\
\hline \multicolumn{2}{|c|}{ Spearman's rs correlation coefficient } & \multicolumn{2}{|c|}{0.96} \\
\hline
\end{tabular}

*Taken as 8 ppb in calculation of correlation coefficients

The DMA analytical curves were prepared with the dilution of a $1 \mathrm{mg} \mathrm{L}^{-1}$ standard solution (Merck Darmstadt, Germany). Measurements of each sample were duplicated, and analyses were repeated when the coefficient of variability of samples exceeded $5 \%$. The instrument was calibrated using certified reference material INCT-OBTL-5 (tobacco leaves) prior to the measurement, with $\mathrm{Hg}$ content $=20.9 \mathrm{ppb}$. The accuracy did not exceed $2 \%$.

In another $\mathrm{Hg}$ study, with the use of the same analyser type, the accuracy and precision of the determinations were estimated as $\sim 8$ and $6.5 \%$, respectively (Sabatino et al., 2018; see also Sanei et al., 2012). In other papers, these quality indicators of $\mathrm{Hg}$ analyses, frequently partly only reported, are $<10 \%$ (e.g., 4 and 9.5\%, respectively - Nascimento-Silva et al., 2011; Sial et al., 2016; see also Grasby et al., 2015; Jones et al., 2017). Thus, the $\mathrm{Hg}$ contents from the Polish laboratory, considered herein, show similar levels of analytical relatability.

\section{RESULTS}

Comparative analysis of the $\mathrm{Hg}$ values series from the three localities, shown in Tables 1-3 and Figure 2, reveal a close resemblance of ICP-MS and AAS determinations. Unsurprisingly in statistical terms, therefore, covariation of both data sets is very significant, and the Spearman's correlation coefficient is not $<0.95$. Even if background (= median) values vary widely between the successions, from $36.4 \mathrm{ppb}$ at Kahlleite to $263.5 \mathrm{ppb}$ at Novchomok, they display similarly low error levels. Comparing the median abundances, the ICP-MS values are notably constantly heightened by $12.5 \%$ at Lahmida, $17.2 \%$ at Kahlleite, and $29.0 \%$ at the most Hg-enriched Uzbek succession. Mean $\mathrm{Hg}$ values characterize a decreased dispersion, but this estimate is randomly biased by unusually high concentrations.

It is especially significant that the same extraordinarily enriched values of $>1000 \mathrm{ppb}$, are revealed in both data sets, with top value of $5825.3 \mathrm{ppb}$ at Novchomok (if we grant that AAS values approximately reflect real $\mathrm{Hg}$ abundances in the samples analysed). In more detail, for 17 large-scale enrichments ( $>500 \mathrm{ppb}$ ), the relative determination errors by ICP-MS method are randomly distributed and, with one exception, $<20 \%$. In fact, the increased $\mathrm{Hg}$ values locate in the AAS analysis error field in the case of $>70 \%$ enriched samples (Fig. 3).

When comparing particular samples, some divergences are very distinctive. As exemplified by sample K 1, the very low ICP-MS value below the DL (10 ppb) is not confirmed by AAS determination (22.5 ppb). By contrast, a fabricated "enrichment" is noted for sample K 4 (20 instead of $8.5 \mathrm{ppb}$ ), and similarly 
$\mathrm{Hg}$ abundances in samples from the Novchomok section using ICP-MS and AAS methods $(\mathrm{Hg}$ enrichments $>0.5 \mathrm{ppm}$ in AAS values are highlighted)

\begin{tabular}{|c|c|c|c|}
\hline \multirow{3}{*}{ Stage } & Sample & $\mathrm{Hg}$ & $\mathrm{Hg}$ \\
\hline & Method & ICP-MS & AAS \\
\hline & Method detection limit (MDL) & $10 \mathrm{ppb}$ & $0.2 \mathrm{ppb}$ \\
\hline \multirow{8}{*}{ TOURNAISIAN } & NOV $22 / 9$ & 120 & 102.6 \\
\hline & NOV 22 /6 & 340 & 294.7 \\
\hline & NOV $22 / 5$ & 490 & 373.3 \\
\hline & NOV $22 / 3$ & 130 & 80.4 \\
\hline & NOV $22 / 2$ & 140 & 94.6 \\
\hline & NOV $22 / 1$ & 160 & 119.9 \\
\hline & NOV $22 / 0$ & 130 & 83.7 \\
\hline & NOV 22 /01 & 230 & 173.4 \\
\hline \multirow{17}{*}{ FAMENNIAN } & NOV 22 /02 & 630 & 756.2 \\
\hline & NOV 22 /03 & 190 & 100.9 \\
\hline & NOV 22 /04 & 250 & 127.9 \\
\hline & NOV $22 / 05$ & 1320 & 1512.5 \\
\hline & NOV 22 /06 & 280 & 179.9 \\
\hline & NOV 22_07 & 310 & 151.9 \\
\hline & NOV 22 /08 & 2430 & 2068.4 \\
\hline & NOV 22 /09A & 2430 & 1186.6 \\
\hline & NOV 22_09 B & 3970 & 4331.5 \\
\hline & NOV $22 / 010$ & 4810 & 5825.3 \\
\hline & NOV 22_011 & 360 & 263.5 \\
\hline & NOV $22 / 012$ & 550 & 352.9 \\
\hline & NOV 22_013 & 680 & 595.0 \\
\hline & NOV 22 /014 & 260 & 200.1 \\
\hline & NOV 22_015 & 610 & 457.7 \\
\hline & NOV $22 / 016$ & 900 & 730.3 \\
\hline & NOV 22 /020 & 300 & 238.7 \\
\hline \multicolumn{2}{|l|}{ Median/mean value } & $340 / 860$ & $263.5 / 794.8$ \\
\hline \multicolumn{2}{|c|}{ Linear correlation coefficient } & \multicolumn{2}{|c|}{0.97} \\
\hline \multicolumn{2}{|c|}{ Spearman's rs correlation coefficient } & \multicolumn{2}{|c|}{0.98} \\
\hline
\end{tabular}

large differences are found for the sub-background abundances of the samples NOV 22 /04 and 07 at Novchomok. Likewise, the $\mathrm{Hg}$ content of the near F-F boundary sample from Lahmida is shown as three times higher in the ICP-MS measurement (110 ppb versus $36.9 \mathrm{ppb}$ ). Among truly enriched samples, the only noteworthy deviation is in an Uzbek sample NOV 22 /09A, for which $\mathrm{Hg}$ values are doubled in the ICP-MS measurements (2430 versus $1186.6 \mathrm{ppb}$ ). On the other hand, a maximal "impoverishment" by $17.4 \%$ is noted for the extreme value in sample NOV $22 / 010$ in the same section (4810 versus $5825.3 \mathrm{ppb})$.

\section{DISCUSSION}

Since 2011 we have established a database for $\mathrm{Hg}$ abundances, determined largely by ICP-MS, for 17 F-F sections and $11 \mathrm{D}-\mathrm{C}$ localities in different regions of the world, revealing several variously recorded anomalous $\mathrm{Hg}$ spikes, up to $8 \mathrm{ppm}$ in the F-F boundary beds (Psie Górki, Holy Cross Mts., Poland) and $18.5 \mathrm{ppm}$ in the D-C boundary beds (Kronhofgraben, Carnic Alps, Austria). However, only the refined AAS values are commonly accepted and widely regarded as reliable in the discussion of potential volcanic signals. Therefore, we have tested the $\mathrm{Hg}$ chemostratigraphic pattern arising from less reliable ICP-MS results. Both analytical methods clearly reveal a similar $\mathrm{Hg}$ chemostratigraphic pattern in the successions studied (see Fig. 2), as well as showing high correlation values of the measured values, even for the lowest $\mathrm{Hg}$ abundances (<40 ppb; Fig. 3A). With one exception (Fig. 3B), the largest analytical errors occur notably in values below or at most near the $\mathrm{Hg}$ baselines in the sections we studied. So, proportionally large discrepancies may be influenced not only by the analytical procedure weakness of the ICP-MS standard, but also by insufficient homogenization of the rock powders of the samples analysed, among other factors.

Six samples under study display concentrations below the DL of the ICP-MS method (10 ppb). For the purpose of calculation, half of the $\mathrm{DL}$ value is commonly adopted (e.g., Riboulleau et al., 2018), i.e., 5 ppb in the case of $\mathrm{Hg}$ (Fig. 3A). However, excluding the abnormally inconsistent sample $\mathrm{K} 1$, dispersion of the remaining values (from 5.2 to $9.9 \mathrm{ppb}$ ) suggests that $\mathrm{Hg}$ values between 7 and $8 \mathrm{ppb}$ are far more representative.

Both methods characterize the successions as including prominent $\mathrm{Hg}$ excursions, for 12 samples $>1000 \mathrm{ppb}$ (1 ppm), 

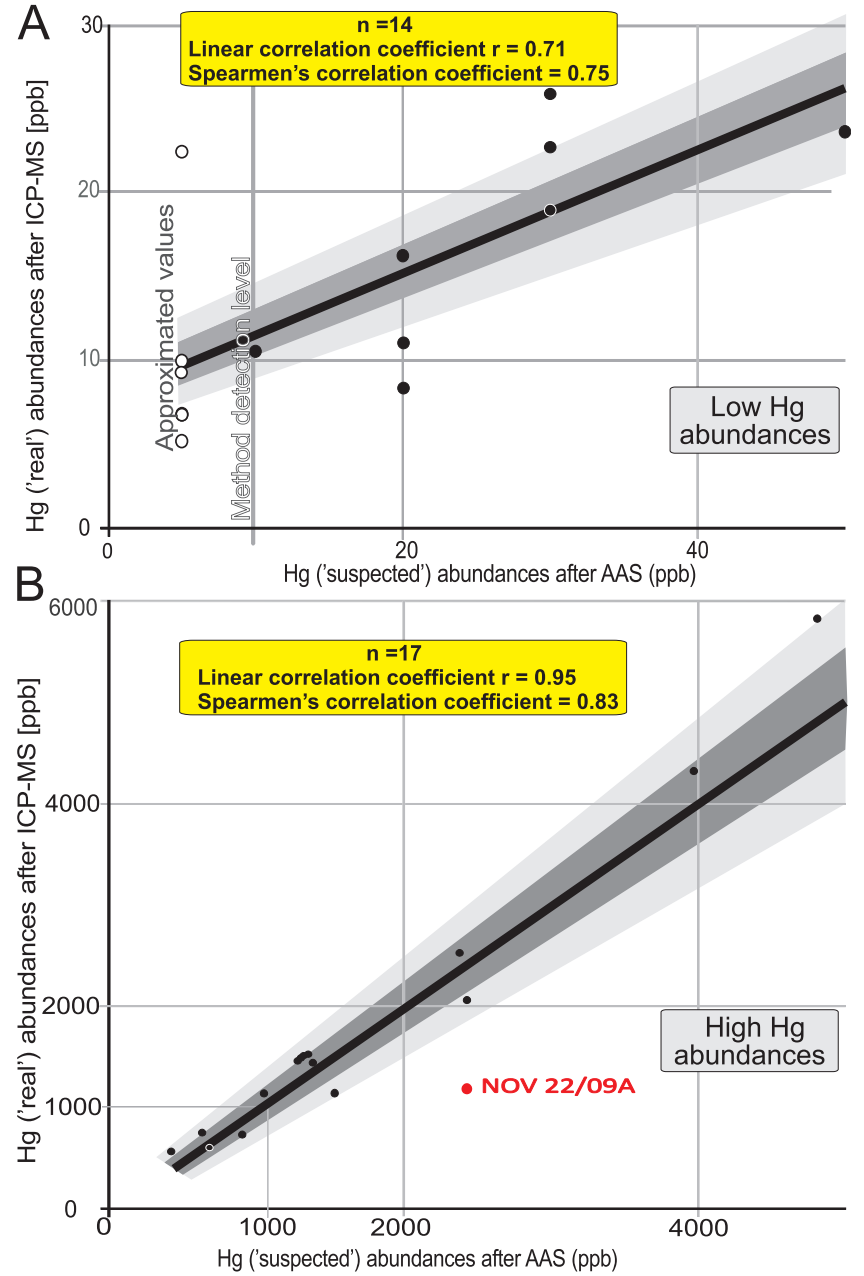

Fig. 3. Correlation of low, less than $40 \mathrm{ppb}(\mathrm{A})$, and high, $>500 \mathrm{ppb}$ (B), mercury abundances provided by ICP-MS and ASS for three Upper Devonian sections (Fig. 2)

Note the generally highly coherent covariation of both $\mathrm{Hg}$ data sets, with the most significant exception of the sample NOV 22 /09A from the D-C transition in Uzbekistan. The dark grey field shows a maximum error range in the AAS measurements (taken as $10 \%$ after Sabatino et al., 2018; includes $70.6 \%$ ICP-MS values), and the light grey field indicates a $20 \%$ determination error range, that encompasses $94 \%$ ICP-MS determinations. Values below the detection level were approximated after Riboulleau et al. (2018)

in particular directly below the F-F and D-C boundaries (Fig. 2). Notably, Wedepohl's (1991) averaged Phanerozoic Hg concentrations range from $30 \mathrm{ppb}$ (limestone) to $450 \mathrm{ppb}$ (argillaceous shale). Also, Ketris and Yudovich (2009) calculated the diverse shale-averaged abundances as between 180 $\pm 30 \mathrm{ppb}$ (cherty shales) and $290 \pm 30 \mathrm{ppb}$ (calcareous shale), and an averaged $\mathrm{Hg}$ abundance of $270 \pm 30$ ppb for black shales. Therefore, the $\mathrm{Hg}$ anomalies recognized for the first time in Upper Devonian strata are approximately one (Lahmida, Novchomok) to two (Kahlleite) orders of magnitude higher compared to the baselines for those successions, as well as to the expected world averages. This status is maintained even for the most abnormally biased ICP-MS value of the highly enriched sample NOV 22/09 (Figs. 2 and 3).
The association of anomalous $\mathrm{Hg}$ excursions with a cataclysmic LIP trigger at the F-F and D-C global events is an attractive hypothesis (Racki et al., 2018), especially in the light of some recent views on a causal role of the Siberian Viluy LIP (e.g., Kravchinsky, 2012; Ricci et al., 2013; see also Winter, 2015; Fig. 1), but other alternatives need to be considered. Enrichments of a similar order (1570 ppb), determined from ICP-MS values, have already been reported from the supposed Upper Kellwasser level in coastal facies of Catalonia, Spain, by Moreno et al. (2018), but interpreted exclusively as a signature of local hydrothermal activity, notably intense in the closing, north-subducting Rheic Ocean (Winter, 2015; Raumer et al., 2017; see Fig. 1). In fact, an occurrence of regional and local Hg spikes is probable, especially in the palaeogeographic domain strongly affected by Eovariscan volcanism, widespread also in the Saxothuringian zone (Timmerman, 2008) and other regions studied (Simancas et al., 2005; Michard et al., 2010; Han and Zhao, 2018).

$\mathrm{Hg}$ anomalies may indeed have multiple origins, and also record "increased preservation of $\mathrm{Hg}$ within sediments either through increases in deposition via scavenging/absorption onto particles or post-depositional migration of $\mathrm{Hg}$ within the sediments" (Bergquist, 2017: p. 8675). In case of the K-Pg enrichments of $\mathrm{Hg}$ at Bidart (France), a hypothesis of "postdepositional geochemical leaching and reduction processes" has been proposed by Smit et al. (2016) in place of a Deccan LIP derived $\mathrm{Hg}$ delivery. In addition, as shown by Zheng et al. (2018) in coal basins, Hg concentration patterns are significantly affected by secondary magmatic phenomena, such as flows of magmatic-hydrothermal and low-temperature hydrothermal fluids, and by elevated heat and pressure due to intruding magmas. Therefore, the distinction between global (= widely distributed and synchronously recorded) signals and diversity of regional noise is a novel challenge in $\mathrm{Hg}$ chemostratigraphy (Racki et al., 2018).

\section{CONCLUSIONS}

A preliminary test of two analytical methods of $\mathrm{Hg}$ determination negates the view that ICP-MS values are unreliable, and generate of false signals. Despite some differences between the $\mathrm{Hg}$ data sets, especially at low $\mathrm{Hg}$ levels (sporadically even two to three times overstated by ICP-MS), both analytical methods reveal the same extraordinarily enriched samples in the F-F and D-C boundary beds under study. The overall chemostratigraphic pattern is also similar, characterized by a few prominent $\mathrm{Hg}$ excursions in excess of $1 \mathrm{ppm}$. The values of $\mathrm{Hg}$ determined by ICP-MS and AAS are, therefore, significantly correlated, even if the first method reveals a general tendency towards slightly heightened values (by 15 to $30 \%$ for medians).

In summary, conventional ICP-MS results can conclusively be used in mercury chemostratigraphy in order to recognize extraordinary volcanic (or other) signals, undoubtedly related to the geological record of Devonian global events. False anomalies are not generated by the $\mathrm{Hg}$ determinations.

Acknowledgements. The study was supported by the MAESTRO grant 2013/08/A/ST10/00717 from the National Science Centre - Poland (to Grzegorz Racki). We warmly thank Z. Bełka, M. Gereke, U. Rakhmonov, N. Abdiev, F. Salimova, and other participants in the grant field works. Constructive remarks by the journal reviewers Z. Sawłowicz, J. Kalvoda and T. Becker are greatly appreciated. We also thanks I. Milińska and R. Fikier for laboratory works. 


\section{REFERENCES}

Bergquist, A.B., 2017. Mercury, volcanism, and mass extinctions. Proceedings of the National Academy of Sciences of the United States of America, 114: 8675-8677.

Bond, D.P.G., Grasby, S.E., 2017. On the causes of mass extinctions. Palaeogeography, Palaeoclimatology, Palaeoecology, 478: 3-29.

Calvert, S.E., Pedersen, T.F., 2007. Elemental proxies for palaeoclimatic and palaeoceanographic variability in marine sediments: interpretation and application. Developments in Marine Geology, 1: 567-644

Dopieralska, J., 2003. Neodymium isotopic composition of conodonts as a palaeoceanographic proxy in the Variscan oceanic system. Ph.D. thesis, Justus-Liebig-University, Giessen.

Dopieralska, J., 2009. Reconstructing seawater circulation on the Moroccan shelf of Gondwana during the Late Devonian: evidence from Nd isotope composition of conodonts. Geochemistry, Geophysics, Geosystems, 10: 1-10.

Eckelmann, K., Nesbor, H.-D., Königshof, P., Linnemann, U., Hofmann, M., Lange, J.-M., Sagawe, A., 2014. Plate interactions of Laurussia and Gondwana during the formation of Pangaea - constraints from U-Pb LA-SF-ICP-MS detrital zircon ages of Devonian and Early Carboniferous siliciclastics of the Rhenohercynian zone, Central European Variscides. Gondwana Ressearch, 25: 1484-1500.

Franke, W., Cocks, L.R.M., Torsvik, T.H., 2017. The Palaeozoic Variscan oceans revisited. Gondwana Research, 48: 257-284.

Gereke, M., 2004. Das Profil Kahlleite Ost - die stratigraphische Entwicklung einer Tiefschwelle im Oberdevon des Bergaer Sattels (Thüringen). Geologica et Palaeontologica, 38: 1-31.

Gereke, M., 2007. Die oberdevonische Kellwasser-Krise in der Beckenfazies von Rhenoherzynikum und Saxothuringikum (spätes Frasnium/frühestes Famennium, Deutschland). Kölner Forum für Geologie und Paläontologie, 17: 1-228.

Gereke, M., Schindler, E., 2012. "Time-Specific Facies" and biological crises - the Kellwasser Event interval near the Frasnian/Famennian boundary (Late Devonian). Palaeogeography, Palaeoclimatology, Palaeoecology, 367-368: 19-29.

Golonka, J., 2012. Paleozoic paleoenvironment and Paleolithofacies Maps of Gondwana. AGH University of Science and Technology Press.

Golonka, J., Ross, M.I., Scotese, C.R., 1994. Phanerozoic paleogeographic and paleoclimatic modeling maps. Canadian Society of Petroleum Geologists Memoir, 17: 1-47.

Grasby, S.E., Beauchamp, B., Bond, D.P.G., Wignall, P.B., Talavera, C., Galloway, J.M., Piepjohn, K., Reinhardt, L., Blomeier, D., 2015. Progressive environmental deterioration in NW Pangea leading to the latest Permian extinction. GSA Bulletin, 127: 1331-1347.

Han, Y.G., Zhao, G.C., 2018 (in press). Final amalgamation of the Tianshan and Junggar orogenic collage in the southwestern Central Asian Orogenic Belt: constraints on the closure of the Paleo-Asian Ocean. Earth-Science Reviews, https://doi.org/10.1016/j.earscirev.2017.09.012

Hartenfels, S., 2011. Die globalen Annulata-Events und die Dasberg-Krise (Famennium, Oberdevon) in Europa und Nord-Afrika - hochauflösende Conodonten-Stratigraphie, Karbonat-Mikrofazies, Paläoökologie und Paläodiversität. Münstersche Forschungen zur Geologie und Paläontologie, 105: 17-527.

Hildebrand, A.R., Boynton, W.V., 1989. Hg anomalies at the K/T boundary: evidence for acid rain? Meteoritics, 24: 277-278.

Jones, D.S., Martini, A.M., Fike, D.A., Kaiho, K., 2017. A volcanic trigger for the Late Ordovician mass extinction? Mercury data from south China and Laurentia. Geology, 45: 631-634.

Ketris, M.P., Yudovich, Y.E., 2009. Estimations of Clarkes for carbonaceous biolithes: world averages for trace element contents in black shales and coals. International Journal of Coal Geology, 78: $135-148$.
Kravchinsky, V.A., 2012. Paleozoic large igneous provinces of Northern Eurasia: correlation with mass extinction events: Global and Planetary Change, 86-87: 31-36.

Michard, A., Soulaimani, A., Hoepffner, C., Ouanaimi, H., Baidder, L., Rjimati, E.C., Saddiqi, O., 2010. The South-Western Branch of the Variscan Belt: evidence from Morocco. Tectonophysics, 492: 1-24.

Moreno, C., Gonzalez, F., Sáez, R., Melgarejo, J.C., SuárezRuiz, I., 2018. The Upper Devonian Kellwasser Event recorded in a regressive sequence from inner shelf to lagoonal pond, Catalan Coastal Ranges, Spain. Sedimentology, 65: doi: 10.1111/sed.12457

Narkiewicz, K., Rakociński, M., Corradini, C., Racki, G., 2017 New conodont data from the Devonian-Carboniferous boundary interval in the Kitab Reserve Area (Uzbekistan). Cuadernos del Museo Geominero, 22: 183-184.

Nascimento-Silva, V.M., Sial, A.N., Ferreira, V.P., Neumann, V.H., Barbosa, J.A., Pimentel, M.M., Lacerda, L.D., 2011. Cretaceous-Paleogene transition at the Paraíba Basin, northeastern, Brazil: carbon-Isotope and mercury subsurface stratigraphies. Journal of South American Earth Sciences, 32: 379-392.

Palinkaš, A.L., Drobne, K., Durn, G., Miko, S., 1996. Mercury anomaly at the Cretaceous-Tertiary boundary: Dolenja Vas, Slovenia (abstract). In: International Workshop Postojna '96. The Role of Impact Processes in the Geological and Biological Evolution of Planet Earth: 31-32.

Percival, L.M.E., Witt, M.L.I., Mather, T.A., Hermoso, M., Jenkyns, H.C., Hesselbo, S.P., Al-Suwaidi, A.H., Storm, M.S., Xu, W., Ruhl, M., 2015. Globally enhanced mercury deposition during the end-Pliensbachian extinction and Toarcian OAE: a link to the Karoo-Ferrar Large Igneous Province. Earth and Planetary Science Letters, 428: 267-280.

Percival, L.M.E., Ruhla, M., Hesselbo, S.P., Jenkyns, H.C., Mather, T.A., Whiteside, J.H., 2017. Mercury evidence for pulsed volcanism during the end-Triassic mass extinction. Proceedings of the National Academy of Sciences of the United States of America, 114: 7929-7934.

Pyle, D.M., Mather, T.A., 2003. The importance of volcanic emissions for the global atmospheric mercury cycle. Atmospheric Environment, 37: 5115-5124.

Racki, G., Rakociński, M., Marynowski, L., Wignall, P.B., 2018. Mercury enrichments and the Frasnian-Famennian biotic crisis: a volcanic trigger proved? Geology, 46: 543-546.

Ramkumar, M. ed., 2015. Chemostratigraphy. Concepts, Techniques, and Applications. Elsevier, Amsterdam.

Rampino, M.R., 2017. Cataclysms. A New Geology for the Twenty-first Century. Columbia University Press, New York.

Raumer, J.F., Nesbor, H.D., Stampfli, G.M., 2017. The north-subducting Rheic Ocean during the Devonian: consequences for the Rhenohercynian ore sites. International Journal of Earth Sciences, 106: 2279-2296

Riboulleau, A., Spina, A., Vecoli, M., Riquier, L., Quijada, M., Tribovillard, N., Averbuch, O., 2018. Organic matter deposition in the Ghadames Basin (Libya) during the Late Devonian: a multidisciplinary approach. Palaeogeography, Palaeoclimatology, Palaeoecology, 497: 37-51.

Ricci, J., Quidelleur, X., Pavlov, V., Orlov, S., Shatsillo, A., Courtillot, V., 2013. New ${ }^{40} \mathrm{Ar} /{ }^{39} \mathrm{Ar}$ and $\mathrm{K}-\mathrm{Ar}$ ages of the Viluy traps (Eastern Siberia): further evidence for a relationship with the Frasnian-Famennian mass extinction. Palaeogeography, Palaeoclimatology, Palaeoecology, 386: 531-540.

Sabatino, N., Ferraro, S., Coccioni, R., Bonsignore, M., Del Core, M., Tancredi, V., Sprovieri, M., 2018. Mercury anomalies in upper Aptian-lower Albian sediments from the Tethys realm. Palaeogeography, Palaeoclimatology, Palaeoecology, 495: 163-170. 
Sageman, B.B., Lyons, T.W., 2003. Geochemistry of fine-grained sediments and sedimentary rocks. Treatise on Geochemistry, 7: 15-158.

Sanei, H., Grassby, S.E., Beauchamp, B., 2012. Latest Permian mercury anomalies. Geology, 40: 63-66.

Saupe, A., Hartenfels, S., Becker, R.T., 2016. Agglutinating foraminifers around the Annulata Events and Dasberg Crisis (Famennian, Upper Devonian) - palaeoecology and palaeodiversity. In: 87th Annual Conference of the Paläontologische Gesellschaft, Dresden, 2016: 134.

Sial, A.N., Gaucher, C., Silva Filho, M.A., Ferreira, V.P., Pimentel, M.M., Lacerda, L.D., Silva Filho, E.V., Cezario, W., 2010. C-, Sr-isotope and Hg stratigraphies of Neoproterozoic cap carbonates of the Sergipano Belt, Northeastern Brazil. Precambrian Research, 182: 351-372.

Sial, A.N., Chen, J., Lacerda, L.D., Frei, R., Tewari, V.C., Pandit, M.K., Gaucher, C., Ferreira, V.P., Cirillis, S., Peralta, S., Korte, C., Barbosa, J.A., Pereira, N.S., 2016. Mercury enrichments and $\mathrm{Hg}$ isotopes in Cretaceous-Paleogene boundary successions: links to volcanism and paleoenvironmental impacts. Cretaceous Research, 66: 60-81.

Simancas, J.F., Tahiri, A., Azor, A., González-Lodeiro, F., Martinez Poyatos, D.J., El Hadi, H., 2005. The tectonic frame of the Variscan-Alleghanian orogen in Southern Europe and Northern Africa. Tectonophysics, 398: 181-198.

Smit, J., Koeberl, C., Claeys, P., Montanari, A., 2016. Mercury anomaly, Deccan volcanism, and the end-Cretaceous mass extinction: comment. Geology, 44: e381.

Stampfli, G.M., Borel, G.D., 2002. A plate tectonic model for the Paleozoic and Mesozoic constrained by dynamic plate boundaries and restored synthetic oceanic isochrones. Earth and Planetary Science Letters, 196: 17-33.
Thibodeau, A.M., Bergquist, A.B., 2017. Do mercury isotopes record the signature of massive volcanism in marine sedimentary records? Geology, 45: 95-96.

Timmerman, M.J., 2008. Palaeozoic magmatism. In: The Geology of Central Europe: Precambrian and Palaeozoic (ed. T. McCann): 665-748, 1. Geological Society, London.

Tribovillard, N., Algeo, T.J., Lyons, T., Riboulleau, A., 2006. Trace metals as paleoredox and paleoproductivity proxies: an update. Chemical Geology, 232: 12-32.

WedepohI, K.H., 1991. The composition of the upper earth's crust and the natural cycles of selected metals. Metals in natural raw materials. Natural Resources. In: Metals and their Compounds in the Environment (ed. E. Merian): 3-17. Verlag Chemie (VCH), Weinheim.

Wendt, J., Belka, Z., 1991. Age and depositional environment of Upper Devonian (Early Frasnian to Early Famennian) black shales and limestones (Kellwasser Facies) in the Eastern AntiAtlas, Morocco. Facies, 25: 51-90.

Weyer, D., 2016. Review of some Frasnian ahermatypic coral localities from Germany and description of a new genus Spinaxon (Anthozoa, Rugosa, Upper Devonian). Geologica Belgica, 19: 147-163.

Winter, J., 2015. Vulkanismus und Kellwasser-Krise - Zirkon-Tephrostratigrafie, Identifizierung und Herkunft distaler Fallout-Aschenlagen (Oberdevon, Synklinorium von Dinant, Rheinisches Schiefergebirge, Harz). Zeitschrift der Deutschen Gesellschaft für Geowissenschaften, 166: 227-251.

Zheng, L., Sun, R., Hintelmann, H., Zhu, J., Wang, R., Sonke, J.E., 2018. Mercury stable isotope compositions in magmatic-affected coal deposits: new insights to mercury sources, migration and enrichment. Chemical Geology, 479: 86-101. 